\title{
WILEY

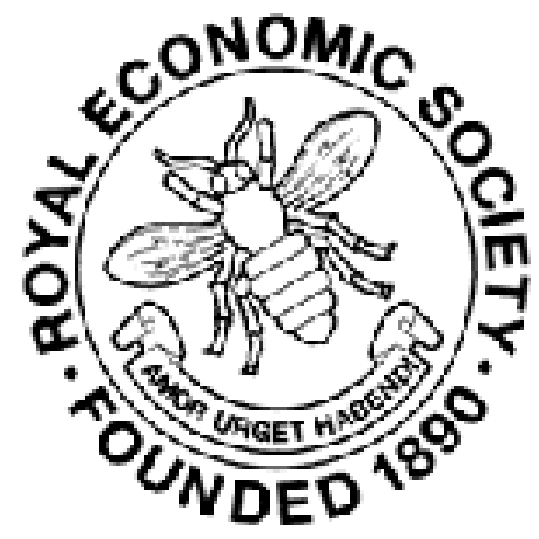

A Plain Statement of the Currency Question with Reasons Why We Should Restore the Old English Law of Bimetallism by John Hill Twigg

Review by: F. C. Harrison

The Economic Journal, Vol. 3, No. 11 (Sep., 1893), p. 507

Published by: Wiley on behalf of the Royal Economic Society

Stable URL: http://www.jstor.org/stable/2955710

Accessed: 11/02/2015 22:21

Your use of the JSTOR archive indicates your acceptance of the Terms \& Conditions of Use, available at http://www.jstor.org/page/info/about/policies/terms.jsp

JSTOR is a not-for-profit service that helps scholars, researchers, and students discover, use, and build upon a wide range of content in a trusted digital archive. We use information technology and tools to increase productivity and facilitate new forms of scholarship. For more information about JSTOR, please contact support@jstor.org.

Wiley and Royal Economic Society are collaborating with JSTOR to digitize, preserve and extend access to The Economic Journal. 
which, moreover, an import duty was imposed, the main burden probably fell on the colonial grower. It was, in fact, a partial land tax. The chief direct levy was the poll tax, also a primitive form of revenue. The other fiscal expedients were of the same character, especially the tobacco-notes, which were a form of warehouse-warrant used to obviate the scarcity of metallic money. The general property tax did not come into existence till much later.

C. F. Bastable

\section{SOME RECENT WORKS ON CURRENCY.}

\section{A Plain Statement of the Currency Question; with Reasons why we should Restore the old English Law of Bimetallism. By JoHn HiLl Twigg. (London: Effingham Wilson.)}

THE time has gone by, it seems to us, for so simple a restatement of the bimetallic position as that made by Mr. Twigg. The difficulties of the creed are slurred over without an adequate appreciation of the arguments advanced by opponents.

If falling prices be an evil, it is not apparent why bimetallism is the 'only practicable' remedy. It is a much controverted question whether the existing stocks of gold and silver are not so earmarked that fresh supplies have a considerable effect on prices. Mr. Giffen denies that America's silver secures her note issue. He contends it is surplusage. Mr. Twigg goes too far in stigmatizing a creditor as 'dishonest' who prefers an appreciating currency. Is it so certain that Germany, Russia, and Austria will follow England into bimetallism if the latter holds up her finger?

\section{A Colloquy on Currency. By Henry Hucks Gibbs. (London: Effingham Wilson.)}

Mr. GrBbs's last effort is more discursive than the pamphlet already noticed, but at the same time on a far higher plane, whilst the writing is easy, unaffected, and lively. On page 33 he characterizes the supposition that gold might, under bimetallic conditions, disappear from circulation as, 'saving better instruction, supremely ridiculous and wholly superfluous.' The strength of this language suggests weakness in the reasoning. Soetbeer has estimated that the greater part of the gold annually produced is at present hoarded or used in the arts. There is nothing ' ridiculous' in the idea that under bimetallism (particularly with a ratio favourable to silver) gold may be in greater demand for the arts than for currency, silver and silver notes becoming the universal medium of exchange. On page 42 it is forcibly urged as against Dr. Giffen that the French minț were, as a fact, closed to silver not on 